\title{
囚人のディレンマゲームのゲーム行動におよぼす対面の効果 ${ }^{1}$
}

九州大学山内隆次

The effect of face-to-face playing on choice behavior in prisoner's dilemma game

Takahisa Yamauchi (Department of Educational Psychology, Faculty

of Education, Kyushu University, Higashi-ku, Fukuoka 812)

Two experiments were conducted to examine the effects of face-to-face playing on choice behavior in prisoner's dilemma games. Subjects were female undergraduates. Experiment I showed that the subjects under the face-to-face condition played less competitively than those under the non-face-to-face condition in a game with the matrix composed of plus scores and minus scores. Experiment II showed that the subjects under the face-to-face condition played more competitively than those under the non-face-to-face condition in a game with the matrix composed of only plus scores. It was suggested that face-to-face playing facilitated the behavior avoiding the subject's and her partner's minus scores in the first game and the behavior outscoring the partner in the second game.

Key words : prisoner's dilemma games, cooperation, competition, face-to-face condition, non-faceto-face condition, plus scores and minus scores of game matrices.

本研究は非ゼロ和ゲームの 1 つである囚人のディレン マゲーム（以下 PD ゲームと略す）に秃いてプレイヤー 相互の対面の有無がプレイヤーのゲーム行動に拉よ汸す 効果沉いて検討する.

実験社会心理学で用いられる PD ゲームは，2 者間の 対人関係の研究方法として頻繁に利用されてきた. この PD ゲームは一般に Fig. 1 亿示す $2 \times 2$ の利得マトリッ クスで表わされる. 利得の左の項はプレイヤー A の利得 を，右の項はプレイヤーBの利得を示するのとする，そ して $\mathrm{X}_{1}, \mathrm{X}_{2}, \mathrm{X}_{3}, \mathrm{X}_{4}$ の大小の関係は, (1) $2 \mathrm{X}_{1}>\mathrm{X}_{2}+$ $\mathrm{X}_{3}$ ，(2) $\mathrm{X}_{3}>\mathrm{X}_{1}>\mathrm{X}_{4}>\mathrm{X}_{2}$ である。このようなマトリッ クスで示されるとき方略 $a_{1}, b_{1}$ を協同的方略, $a_{2}, b_{2}$ を 競争的方略と呼ぶ (Rapoport \& Orwant, 1962; Nemeth, 1972).

しかし，一般に PD ゲームに捻いては集団の合理解で 㐫る協同的方略選択反応 (以下, 協同選択とする. また 㜔争的方略選択反応を競争選択とする) はあらわれにく いと指摘されている(Minas, Scodel, Marlowe, \& Raw-

1 本論文は 1978 年に九州大学大学院教育学研究科に 提出した修士論文の一部に新たな実験データを加え, ま とめ直したものである。

2 本論文の作成にあたり御指導いただいた九州大学教 育学部狩野素朗教授, 実験に際乙御援助いただいた熊本 大学教養部重岡和信教授, 有益な助言をいただいた熊本 大学教育学部鈴木康平教授に深く感謝いたします。 son, 1960). Nemeth (1972) は PD ゲームを用いた取 引 (bargaining) の諸研究を通覽して, 協同選択率が約 30\%の低い值であったことを示している. その理由と して, Nemeth は協同選択率の低さが実験事態に基づく ものであると指摘し，これらの研究の実験事態が，一般 に被験者であるプレイヤーにとって各々相手プレイヤー が視覚的, 聴覚的に隔離された状態で行なわれ，㐫たか も実験者相手に 1 人でプレイしている状態ではなかった かと述べている.つまり，PD ゲームが效人関係のシュ ミレーションとして有効性を高めるためには, 相互に助 计合うといら社会的規範, 互恵性 (reciprocity) を喚起 する対面事態での研究を行なうことが重要であると指摘 している. Wichman (1970) は, $\left(\mathrm{X}_{1}, \mathrm{X}_{1}\right)=(3,3)$, $\left(\mathrm{X}_{3}, \mathrm{X}_{2}\right)=(5,0), \quad\left(\mathrm{X}_{2}, \mathrm{X}_{3}\right)=(0,5), \quad\left(\mathrm{X}_{4}, \mathrm{X}_{4}\right)=(1$, 1) の利得マトリックスを用いて，(1)相互に相手を見て 話すことのできる群, (2)話すだけの群, (3)見るだけの 群，(4)隔離群を設定し，それぞれのゲーム行動を比較し たところ, (1), (2), (3), (4)の順で協同選択率が高かったこ

$$
\begin{array}{ccc} 
& \multicolumn{2}{c}{\text { Player B }} \\
& \mathrm{b}_{1} & \mathrm{~b}_{2} \\
\text { Player A } & \mathrm{a}_{1}\left(\mathrm{X}_{1}, \mathrm{X}_{1}\right) & \left(\mathrm{X}_{2}, \mathrm{X}_{3}\right) \\
\mathrm{a}_{2}\left(\mathrm{X}_{3}, \mathrm{X}_{2}\right) & \left(\mathrm{X}_{4}, \mathrm{X}_{4}\right)
\end{array}
$$

Fig. 1. The generalized pay-off matrix of prisoner's dilemma game. 
とを報告した。ささらに，(1)と(3)を合わせた見ることので きるプレイヤー（対面プレイヤー）は, (2)と(4)を合わせ た見ることのできないプレイヤー（非対面プレイヤー） よりも有意に協同選択率が高かったことを見出した。こ の結果について Wichmanは, 対面条件下にあるプレイ ヤー達は競争選択を抑制し協同選択を促進させることを 相互に表情でコントロールしたからだと解釈している.

それでは，プレイヤーが対面する場合には全ての PD ゲームに蛙いて協同選択が促進されるのであろらか。 PD ゲームは大さく協同的動機と競争的動機とが複合的 に喚起されるゲームであると考えられる。また Nemeth の言らあたかも実験者相手にゲームをしているよらな隔 離事態に対し, 対面事態では自他相互に容姿, 表情, 行 為が直接に観察される.Zajonc (1965) の提晿した社会 的促進理論によると, 他者との共行動場面では課題に対 する動機つけが高められるが，複数の行動が可能なとき 可能な行動すべてが促進されるのではなく，その場面の 課題に適合すると被験者の認知した行動が優勢に(dominantly) 促進されると考えられる。これらから, 対面 すると相手プレイヤーの明確化に伴って社会的促進の効 果が働くとすれば，対面するプレイヤーはとうでないプ レイヤーよりも課題適合性の高い行動をとる傾向を強め るであろう. 従って, 協同選択, 競争選択のいずれが多 く生起するかはゲームの構造特性に規定されるであろ 丂.

梅岡・篠塚（1966）は PD ゲームを実験者を含めた 3 人ゼロ和ゲームと仮定し，マイナス得点を含むマトリッ クスを用い，両プレイヤーの前に得点の出し入れをする 実験協力者（銀行）を介在させる実験を行なった．彼ら は銀行の介在がプレイヤーの関係をより協同的にする効 果を見出した。これは，第 3 者 (銀行) が実際に介在す ることで得点が減じることが視覚的に明瞭になり, マイ ナス得点（減点）がより心理的意味を持ったためと考え られる。斉藤・児玉・潮田 (1971) は従来のゲーム事態 に上位の社会関係 (集団間) を導入し，2人を含む集団 と他集団との間に競争関係を設定した。 この結果，同一 集団内のプレイヤー達の行動を協同的にすることに成功 した，彼らは，下位の社会関係（従来のゲームに括ける ペアとしての個人関係) が協同しなければその上位の社 会関係の競争に勝てないときには下位の社会関係の競争 が抑えられると解釈している。をた，上位関係の集団間 競争に勝った後は個人間の競争が再び促進されるといら 結果も合わせて報告している。亦た，山内・狩野(1979) は,プラス得点とマイナス得点の混合した (十・ー) ゲ 一ムのプレイヤーはプラス得点の㕛の（十）ゲームのプ レイヤーよりも協同選択を多くするという結果を報告し た、として, 内省報告の結果から（十）ゲームのプレ イヤーは (+・一) ゲームのプレイヤーに比べ, 得点の
低い共貧セル $\left(\mathrm{X}_{4} 、 \mathrm{X}_{4}\right)$ を多く実現しても得点は確実に 加算されるので安全であると認知して扝り，そのために 競争選択を多くしたと考察している。

これら一連の研究から，自己和よび相手に一定の得点 が保証されている場合に競争する動機が高まるのであ り，その保証が不十分な場合にはをず自己と相手との得 点を一定まで増やそうとする動機が高まるであろう。そ して後者の動機は得点の減少が明瞭であったり自己と相 手を1つの集団として認知したりするときに強くなるで あろらと考えられる。よって, 競争選択が自己特よび相 手の少なくともいずれか一損失一マイナス得点一 を与える可能性のあるゲーム構造の場合には, 対面事態 のプレイヤーはこのマイナス得点を避けよらとする動機 が強められ，その動機に基づいて協同選択を多くする， すなわち競争選択が抑制されると考えられる。一方，マ イナス得点のない，一定水準の得点が保証されたゲーム 構造の場合には，効面事態のプレイヤーは相手と競争す る動機が強められ，競争選択を多くすると考えられる。

そこで, 本研究に氺いては, 対面の効果がゲーム構造 の違いによって異なることを明らかにするために，先に 山内・狩野（1979）が用いた (十・一) ゲームと (十) ゲームといら枠組を用いて検討する。ところで，研究目

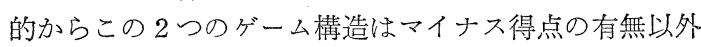
は等しいことが必要であろう。ここでは，2つのゲーム を新たに考案する際に，Rapoport (1967) が提唱したゲ ームマトリックスの協同傾向指数 (Index of cooperation $=\left(\mathrm{X}_{1}-\mathrm{X}_{4}\right) /\left(\mathrm{X}_{3}-\mathrm{X}_{2}\right)$, 以下 IC と略す $)$ が等しく なるよらにした。 Rapoport はゲームマトリックスが固 有に持つ協同選択傾向をマトリックスの各得点のバラン スによって指数化できると考え，いくつかの指数を作っ た.ここで用いる $\mathrm{IC}=\left(\mathrm{X}_{1}-\mathrm{X}_{4}\right) /\left(\mathrm{X}_{3}-\mathrm{X}_{2}\right)$ はその中の 1 つで, 協同選択の増加には $\mathrm{X}_{1}, \mathrm{X}_{2}$ の増加执よび $\mathrm{X}_{1}$ と $\mathrm{X}_{4}$ との差の増大が関与し, 競争選択の増加には $\mathrm{X}_{3}$, $\mathrm{X}_{4}$ の増加抢よび $\mathrm{X}_{3}$ と $\mathrm{X}_{2}$ との差の増大が関与してい ることを示している. また，協同選択と競争選択の間の ディレンマが両選択の誘因価の相対的大きさによって表 わされることを示している. Terhune(1968) は, IC の 大きいゲームのプレイヤーが小さいゲームのプレイヤー より高い協同選択率を示す結果を見出し, この IC の有 効性を実証した. Terhune は, このときマトリックスの $\mathrm{X}_{3}$ と $\mathrm{X}_{2}$ の 2 つだけを変化させて IC を㩭作したが， それは变化させる得点の種類を少なくすることによって 他の要因の入る可能性を小さくするためだったと考学ら れる。しかし，本実験で用いる $(+・-) ケ ゙ ー ム か ら ~ X_{3}$ と $\mathrm{X}_{2}$ の文の変化によって IC の等しい(十) ゲームを 作成すると， 2 つのゲームの $\mathrm{X}_{3}-\mathrm{X}_{1}$ の間に大きな差が 生じる. Ells \& Sermat (1968) は，他の得点が等しく ても $\mathrm{X}_{3}$ が増大することによって $\mathrm{X}_{3}-\mathrm{X}_{1}$ が大きくなる 
と競争選択が多くなることを報告している。これらの知 見を考慮して，本研究では $\mathrm{X}_{1}, \mathrm{X}_{2}, \mathrm{X}_{3}, \mathrm{X}_{4}$ 全てを変 化させることによって， $\mathrm{X}_{2}$ と $\mathrm{X}_{4}$ を除いては (十・一) ゲームの得点 $\mathrm{X}_{n}$ と (十) ゲームの得点 $\mathrm{X}_{n}{ }^{\prime}$ との間に 大きな差を生じさせずに $\mathrm{IC}$ を等しくした。 $\mathrm{X}_{n}$ と $\mathrm{X}_{n}{ }^{\prime}$ の関係は $\mathrm{X}_{n}{ }^{\prime}=\mathrm{X}_{n} / 2+6$ となった。

そして，それぞれのゲームに括いて対面してプレイす る群 (対面群とよぶ) と対面しないでプレイする群（非 対面群とよぶ) の 2 群を設けた。すなわら, 本研究は （十・一）ゲーム，（十）ゲームのそれぞれに拉いて対面 群と非対面群のゲーム行動を比較検討するものである。 以下のように仮説を設定し，実験 Iでは仮説 1 の検討 を，実験吕では仮説 2 の検討を行なう。

1. (+・ー) ゲームに和いては, 対面状況のプレイヤ 一は非詨面状沉のプレイヤーよりる競争選択が少ないで めろら。

2.（十）ゲームに和いては, 対面状況のプレイヤーは 非対面状況のプレイヤーよりも競争選択が多いである 5 .

ところで, ゲーム行動の分析に拈いては, プレイヤー の方略選択を研究者側の観点で協同選択, 競争選択だと 規定している.しかし，プレイヤー自身が自己の方略選 択をどら認知しているかは重要な問題であろら。といら のは，協同選択（競争選択）をプレイヤー自身が協同的 動機（競争的動機）に基づく選択だと認知して当の選択 行動を生起させているという証拠の下で, ゲーム行動の 分析がより確かなるのになると考えられるからである。 よって, 本研究ではプレイヤーの各選択がどのような動 機に基づいて行なわれているかを斉藤 (1975) のカテゴ リーを用いて検討する。

\section{実 験 I}

$\mathrm{X}_{1}$ 抌よび $\mathrm{X}_{3}$ 得点がプラス, $\mathrm{X}_{2}$ 㧊よび $\mathrm{X}_{4}$ 得点が マイナスである正負混合のマトリックスを用い, ゲーム 行動にプレイヤー相互の対面の有無がいかなる影響を与 觉るかを競争選択回数和よび各セルの実現度数の観点か ら検討する。

\section{方 法}

$\mathrm{PD}$ ゲーム 利得マトリックスの各数值は Fig. 2 に示 す.マトリックス内の各得点は各試行でプレイヤーが獲 得できる利得 (ポーカーチップの数) を表わす.

実験条件 実験目的に従って2つの条件群が設定され

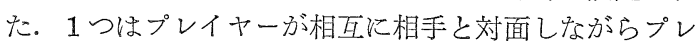
イする群 (以下, 対面群とよぶ) である。他の 1 つは衝 立で隔てられ相互に顔が見えない状態でプレイする群 (以下，非対面群とよぶ) である。

被験者 熊本大学学生女子 24 名で, 対面 6 群ペア 12 名, 非対面群 6 ペア 12 名に分けられた。
質問紙 自己の選択動機を回答させるための質問紙は 斉藤（1975）によった（a)協同的動機（協同的，共栄 関係志向), (b)利他的動機 (相手への配慮, 愛他的), (c)利已的動機 (搾取的, 競争的), (d)防衛的動機 (共 貧報復的, 消極的な利已的), ( e ) 交換的動機 (投資), （f）その他，のいずれかのカテゴリーに含まれる選択肢 が合計 17 個用意された。そして、これらの選択肢が列 記された表から，自己の方略選択の理由に最も近いもの を1つだけ強制選択させた。

手続き 面識のない 2 人の被験者が 1 組にされ実験室 に導入された。このとき被験者同士が顔を合わせないよ らに時間をずらして導かれた。被験者は衝立で隔離され た状態でゲームの説明を受けた。 PD ゲームの一般的な 説明が行なわれた後に，“このゲームでは，先ず各人に 100 点が与光られます.プレイは 20 回行ないます. 20 回終了後の得点がプラス得点だと持ち点に加算され，マ イナス得点だと持ら点から差し引かれます。自分の得点 を高めるょらにして下さい. 残りの得点を 1 点 1 円のレ ートで菓子に換えることができます。なお，ゲーム中は 声を出したり話したりしないで下さい,”と教示された。 教示後, 対面群は衝立がはずされた状態で, 非対面群は 隔離されたままでプレイした。2人は実験者の合図と同 時に, $a_{1}\left(b_{1}\right)$ である赤ランプ (黄ランプ) か, $a_{2}\left(b_{2}\right)$ である青ランプ（緑ランプ）を選択してスイッチを押す よら依頼された。この選択が 20 試行行なわれた。各試 行前に質問紙への回答が行なわれた.

\section{結 果}

まず，質問紙による結果について，各被験者の方略選 択とその動機との関係を検討する.ここでは, 競争選択 を導くと考えられる利己的動機と防衛的動機をまとめて 競争喚起動機, 協同選択を導くと考えられる利他的動機 と協同的動機をまとめて協同喚起動機之呼ぶ. 対面事態 に特いて競争選択が行なわれた際 (75 回) に, 競争喚起 動機が回答されたのは 53 回 $(70.7 \%)$ で，これはそれ 以外の動機が回答された 22 回 $(29.3 \%)$ よりも有意に 多かった $\left(\chi^{2}=12.813, d f=1, p<.001\right)$. また協同選 択が行なわれた際 (165 回), 協同㬇起動機が回答され たのは121回 (73.3\%)でありこれはそれ以外の動機 が回答された 44 回 $(26.7 \%)$ よりも有意に多かった $\left(\mathcal{X}^{2}=35.933, d f=1, p<.001\right)$. 非対面事態でも, 競争 選択が行なわれた際 (123 回), 競争喚起動機が回答され たのは 89 回 (72.4\%) であり，これはそれ以外の動機

Player B $b_{1} \quad b_{2}$
Player A

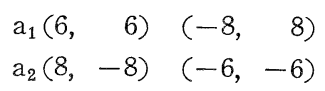

Fig. 2. The pay-off matrix of the $(+\cdots-)$ game. 
Table 1

Mean number of $\mathrm{a}_{2}\left(\mathrm{~b}_{2}\right)$ and $\mathrm{a}_{1}\left(\mathrm{~b}_{1}\right)$ responses, and $\left(\mathrm{X}_{4}, \mathrm{X}_{4}\right),\left(\mathrm{X}_{1}, \mathrm{X}_{1}\right),\left(\mathrm{X}_{3}, \mathrm{X}_{2}\right)$, and $\left(\mathrm{X}_{2}, \mathrm{X}_{3}\right)$ responses on each trial block in the $(+\cdots)$ game ()$=S D$

\begin{tabular}{|c|c|c|c|c|c|c|}
\hline & & Block 1 & Block 2 & Block 3 & Block 4 & Overall \\
\hline \multirow[t]{2}{*}{ Face-to-face } & $a_{2}\left(b_{2}\right)$ & $2.25(1.17)$ & $1.42(1.25)$ & $1.50(1.32)$ & $0.92(1.11)$ & $6.08(3.18)$ \\
\hline & $a_{1}\left(b_{1}\right)$ & $2.75(1.16)$ & $3.58(1.26)$ & $3.50(1.32)$ & 4. $08(1.11)$ & $13.92(3.17)$ \\
\hline \multirow[t]{2}{*}{ Non-face-to-face } & $a_{2}\left(b_{2}\right)$ & $2.67(0.79)$ & $2.50(0.96)$ & $3.08(1.12)$ & $208(1.19)$ & $10.33(2.42)$ \\
\hline & $a_{1}\left(b_{1}\right)$ & $2.33(0.84)$ & $2.50(0.96)$ & $1.92(1.11)$ & $2.92(1.19)$ & $9.67(1.93)$ \\
\hline \multirow[t]{3}{*}{ Face-to-face } & $\left(\mathrm{X}_{4}, \mathrm{X}_{4}\right)$ & $0.67(0.94)$ & $0.33(0.72)$ & $0.17(0.36)$ & $0.17(0.36)$ & $1.33(1.11)$ \\
\hline & $\left(X_{1}, X_{1}\right)$ & $1.17(0.68)$ & $2.50(1.61)$ & $2.17(1.77)$ & $3.33(1.50)$ & $9.17(4.73)$ \\
\hline & $\left|\begin{array}{c}\left(\mathrm{X}_{3}, \mathrm{X}_{2}\right) \\
\text { and }\left(\mathrm{X}_{2}, \mathrm{X}_{3}\right)\end{array}\right|$ & $3.17(0.82)$ & $2.17(1.46)$ & 2. $67(1.97)$ & $1.50(1.61)$ & $9.50(4.11)$ \\
\hline \multirow[t]{3}{*}{ Non-face-to-face } & $\left(\mathrm{X}_{4}, \mathrm{X}_{4}\right)$ & $1.50(0.50)$ & $1.00(1.00)$ & $2.17(1.06)$ & $1.00(0.82)$ & $5.67(1.36)$ \\
\hline & $\left(X_{1}, X_{1}\right)$ & $1.17(0.89)$ & $1.00(0.57)$ & $1.00(1.00)$ & $1.83(1.47)$ & $5.00(2.24)$ \\
\hline & $\left|\begin{array}{c}\left(\mathrm{X}_{3}, \mathrm{X}_{2}\right) \\
\text { and }\left(\mathrm{X}_{2}, \mathrm{X}_{3}\right)\end{array}\right|$ & $2.33(0.49)$ & $3.00(0.57)$ & $1.83(1.07)$ & 2. $17(0.89)$ & $9.33(1.27)$ \\
\hline
\end{tabular}

Note. $a_{2}\left(b_{2}\right)$ : Competitive choice response $a_{1}\left(b_{1}\right)$ : Cooperative choice response

が回答された 34 回 $(27.6 \%)$ よりも有意に多かった $\left(\chi^{2}=24.593, d f=1, p<.001\right)$. また協同選択が行なわ れた際 (117 回), 協同喚起動機が回答されたのは 81 回 (69.2\%)であり，これはそれ以外の動機が回答された 36 回 $(30.8 \%)$ より 有意に多かった $\left(\chi^{2}=17.308, d f=1\right.$, p<.001). これらから, 競争選択括よび協同選択は, 競 争喚起動機あるいは協同喚起動機に裏づけられた行動だ と考学らる.

一般にダーム行動の分析は，プレイヤー個人の協同あ るいは競争選択回数と, 対になった 2 人による共栄セル $\left(\mathrm{X}_{1}, \mathrm{X}_{1}\right)$ ，共貧セル $\left(\mathrm{X}_{4}, \mathrm{X}_{4}\right)$ 沶よび格差セル $\left(\mathrm{X}_{3}\right.$, $\left.\mathrm{X}_{2}\right)\left(\mathrm{X}_{2}, \mathrm{X}_{3}\right)$ の実現度数によって行なわれている。本 研究では，仮説に基づき競争選択回数を中心に分析を行 なう。なお，時系列の分析のため 5 試行 1 ブロックと れ，20試行が 4 ブロックに分けられた。

Table 1 に基つき，競争選択回数を指標として条件 (対面-非対面) と時系列とを要因とする 2 要因分散分析 を行なった，それによると，対面群の競争選択回数は非 対面群のそれよりも有意に少なかった $\left(F_{(1,22)}=14.41\right.$, 名く.01). 対面群の競争選択回数はゲームの進行に従い 有意に減少した $\left(F_{(3,66)}=2.95, p<.05\right)$. 時系列に関す る下位検定の結果, 対面群の競争選択回数は, 第 $2,3,4$ ブロックがそれぞれ第1ブロックよりも少なかった（1 ブロック vs. 2 ブロック $t=1.84, d f=66, p<.05,1$ ブロック vs. 3 ブロック $t=1.67, d f=66, p<.10,1$ ブロック vs. 4 ブロック $t=2.96, d f=66, p<.01$ ).

次に, 2 人 1 組のペア行動について, 共貧セル, 共栄 セルの各実現度数を指標として条件（対面一非対面）と 時系列とを要因とする 2 要因分散分析を行なった。それ
によると，対面群の共貧セル実現度数は非対面群のそれ よりも有意に少なかった $\left(F_{(1,10)}=30.24, p<.01\right)$. 共 貧七ル実現度数への時系列の効果は認められなかった $\left(F_{(3,30)}=1.397, n . s.\right)$. また, 対面群の共栄セル実現度 数は非対面群のそれよりも多い傾向があった $\left(F_{(1,10)}=\right.$ $3.10, p<.10)$. 対面群の及共栄七ル実現度数への時系 列の効果が認められ $\left(F_{(3,30)}=5.83, p<.01\right)$, 第 2 ブロ ックと第 4 ブロックは第 1 ブロックよりも実現度数が 有意に多かった（ 1 ブロック vs. 2 ブロック $t=2.15$, $d f=30, p<.05,1$ ブロック vs. 4 ブロック $t=3.48$, $d f=30, p<.01)$.

\section{実 験 II}

$\mathrm{X}_{1}, \mathrm{X}_{2}, \mathrm{X}_{3}, \mathrm{X}_{4}$ 得点のすべてがプラス得点のマトリ ックスを使用したゲームに和けるゲーム行動にプレイヤ 一相互の対面の有無がいかなる影響を与兄るかを競争選 択回数和よび各セルの実現度数の観点から検討する。

方 法

PD ゲーム 利得マトリックスの各数值は Fig. 3 に示 †.

実験条件 実験目的に従って, 実験 I と同じ手順で詨 面群と非対面群の 2 群が設けられた。

被験者 熊本大学学生女子 24 名で, 対面群 6 ペア 12

$$
\begin{aligned}
& \text { Player B } \\
& \mathrm{b}_{1} \quad \mathrm{~b}_{2} \\
& a_{1}(9,9) \quad(2,10)
\end{aligned}
$$

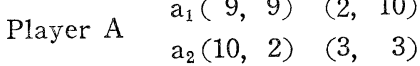

Fig. 3. The pay-off matrix of the $(+)$ game. 
Table 2

Mean number of $\mathrm{a}_{2}\left(\mathrm{~b}_{2}\right)$ and $\mathrm{a}_{1}\left(\mathrm{~b}_{1}\right)$ responses, and $\left(\mathrm{X}_{4}, \mathrm{X}_{4}\right),\left(\mathrm{X}_{1}, \mathrm{X}_{1}\right),\left(\mathrm{X}_{3}, \mathrm{X}_{2}\right)$, and $\left(\mathrm{X}_{2}, \mathrm{X}_{3}\right)$ responses on each trial block in the $(+)$ game ()$=S D$

\begin{tabular}{|c|c|c|c|c|c|c|}
\hline & & Block 1 & Block 2 & Block 3 & Block 4 & Overall \\
\hline \multirow[t]{2}{*}{ Face-to-face } & $a_{2}\left(b_{2}\right)$ & $2.92(0.74)$ & 2. $92(1.25)$ & $2.92(0.95)$ & $3.00(1.29)$ & $11.75(2.42)$ \\
\hline & $a_{1}\left(b_{1}\right)$ & $2.08(0.76)$ & $2.08(1.26)$ & $2.08(0.95)$ & 2. $00(1.29)$ & $8.25(2.42)$ \\
\hline \multirow[t]{2}{*}{ Non-face-to-face } & $a_{2}\left(b_{2}\right)$ & 1. $67(1.17)$ & $0.92(0.95)$ & $1.58(1.61)$ & $1.33(1.49)$ & $5.50(4.52)$ \\
\hline & $a_{1}\left(b_{1}\right)$ & $3.33(1.18)$ & $4.08(0.95)$ & $3.42(1.61)$ & $3.67(1.49)$ & $14.50(4.52)$ \\
\hline \multirow[t]{3}{*}{ Face-to-face } & $\left(\mathrm{X}_{4}, \mathrm{X}_{4}\right)$ & $1.50(0.50)$ & 1. $67(1.24)$ & $1.33(1.25)$ & $2.00(1.82)$ & $6.50(3.69)$ \\
\hline & $\left(X_{1}, X_{1}\right)$ & $0.67(0.46)$ & $0.83(0.69)$ & $0.50(0.76)$ & $1.00(0.82)$ & $3.00(1.00)$ \\
\hline & $\begin{array}{c}\left(\mathrm{X}_{3}, \mathrm{X}_{2}\right) \\
\text { and }\left(\mathrm{X}_{2}, \mathrm{X}_{3}\right)\end{array}$ & $2.83(0.71)$ & $2.50(0.96)$ & $3.17(1.06)$ & $2.00(1.53)$ & $10.50(3.10)$ \\
\hline \multirow[t]{3}{*}{ Non-face-to-face } & $\left(\mathrm{X}_{4}, \mathrm{X}_{4}\right)$ & $0.83(0.90)$ & $0.00(0.00)$ & $1.00(1.15)$ & $0.50(0.76)$ & $2.33(2.43)$ \\
\hline & $\left(\mathrm{X}_{1}, \mathrm{X}_{1}\right)$ & $2.50(1.50)$ & $3.17(1.67)$ & $2.83(2.20)$ & $2.83(1.95)$ & $11.33(6.48)$ \\
\hline & $\left|\begin{array}{c}\left(\mathrm{X}_{3}, \mathrm{X}_{2}\right) \\
\text { and }\left(\mathrm{X}_{2}, \mathrm{X}_{3}\right)\end{array}\right|$ & $1.67(1.10)$ & $1.83(1.83)$ & $1.17(1.46)$ & $1.67(1.37)$ & $6.33(4.20)$ \\
\hline
\end{tabular}

Note. $a_{2}\left(b_{2}\right)$ : Competitive choice response $a_{1}\left(b_{1}\right)$ : Cooperative choice response

名, 非対面群 6 ペア 12 名に分けられた.

質問紙 実験 I と同じ.

手続き 実験Iに準ずる。ただし実験正で使用するマ トリックスにはマイナス得点が含まれていないので, イ ンストラクションの中の減点の説明は除かれた.

\section{結 果}

まず，実験 I と同様に，方略選択とその動機の関係を 調べてみた．対面事態で競争選択が行なわれた際（140 回) に，競争喚起動機功回答されたのは119回(85.0\%) であり，これはそれ以外の動機が回答された 21 回(15.0 \%) よりも有意に多からた $\left(\chi^{2}=68.6, d f=1, \quad p<\right.$ 。001). また協同選択が行なわれた際（100回）に，協同 喚起動機が回答されたのは 65 回 $(65 \%)$ であり，これ はそれ以外の動機が回答された 35 回 $(35 \%)$ よりも有 意に多かった $\left(\chi^{2}=9.00, d f=1, p<.01\right)$. 非対面事態 でも競争選択が行なわれた際 (66回) に，競争喚起動機 が回答されたのは 50 回 $(75.8 \%)$ であり、これはそれ 以外の動機が回答された 16 回 $(24.2 \%)$ よりも有意に 多かった $\left(\chi^{2}=17.515, d f=1, p<.001\right)$. 束た，協同選 択が行なわれた際 (174 回)，協同喚起動機が回答された のは139回 (79.9\%) であり，これはそれ以外の動機が 回答された 35 回 $(20.1 \%)$ よりも有意に多かった $\left(\chi^{2}=\right.$ 62. 161, $d f=1, p<.001)$. これらのことから, 対面群, 非対面群それぞれの競争選択掞よび協同選択は，競争喚 起動機あるいは拹同喚起動機に裏づけられた行動だと考 えられる。

競争選択回数および共貧セル，共栄セル，格差セルの 実現度数をTable 2 に示す. Table 2 に基づき，競争選 択回数を指標として条件 (対面-非対面) と時系列とを要
因とする 2 要因分散分析を行なった。それによると，対 面群の競争選択回数は非対面群のそれよりも多く, この 条件間の差は有意であった $\left(F_{(1,22)}=16.37, p<.01\right)$. 下 位検定により，すべてのブロックにおいて 2 群の間に有 意な差があることが認められた（第 1 ブロック $F_{(1,88)}=$ $5.83, p<.01$, 第 2 ブロック $F_{(1,88)}=14.91, p<.01$, 第 3 ブロック $F_{(1,88)}=6.63, p<.01$, 第 4 ブ.ロック $\left.F_{(1,88)}=10.35, p<.01\right)$. 乙か乙, 時系列の効果はみら いなかった $\left(F_{(3,66)}=0.71, n . s.\right)$.

次に, 2 人 1 組のペア行動について, 共貧セル, 共栄 セルの各実現度数を指標として，条件 (対面一非対面) と 時系列とを要因とする 2 要因分散分析を行なった。その 結果, 対面群の共貧セル実現度数は非対面群のそれより も多く, この条件間の差は有意であった $\left(F_{(1,10} ;=4.46\right.$, $p<.05)$. また，下位検定の結果，第 2 ブロックと第 4 ブロックに执いて両群間の差が有意であり，これが条件 間の差をもたらしたと考䒚られる（第 2 ブロック $F_{(1,40)}$ $=5.91, p<.05$ ，第 4 ブロック $\left.F_{(1,40)}=4.79, p<.05\right)$. 共貧七儿実現度数について時系列の効果は認められなか った $\left(F_{(3,30)}=0.45, n . s.\right)$. 末た, 対面群の共栄セル実 現度数は非対面群のそれよりも有意に少なく，この条件 間の差は有意であった $\left(F_{(1,10)}=8.10, p<.01\right)$. 下位検 定の結果, 全てのブロックに括いて, 対面群の共栄セル 実現度数は非対面群のそれよりも有意に少ないことが認 められた（第 1 ブロック $F_{(1,40)}=4.31, p<.05$, 第 2 ブ ロック $F_{(1,40)}=6.98, p<.05$, 第 3 ブロック $F_{(1,40)}=$ $6.98, p<.05$, 第 4 ブロック $\left.F_{(1,40)}=4.31, p<.05\right)$. 共栄セル実現度数について時系列の効果は認められなか った $\left(F_{(3,30)}=0.48, n . s_{\text {. }}\right)$. 


\section{考}

\section{察}

実験より，ゲームに拈ける対面は，(十・一）ゲー ムではプレイヤーに対して競争選択を少なくさせる効果 をもたらすことが分かった。一方，実験正より，ゲーム に和ける対面は（十）ゲームでは逆にプレイヤーに対し 競争選択を多くさせる效果をもたらすことが分かった。 これらの結果は仮説を支持するものであった。また， Wichman (1970) が用いたゲームはマトリックスが0を 含むものであり最低得点の保証が十分でない点を考慮す

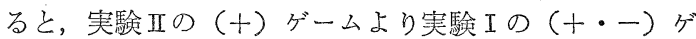
一ムに近い構造をもったゲーム炕と考学られる。そうす ると，Wichman の実験に赫いて対面するプレイヤーが そうでないプレイヤーよりも協同的であった——競争選 択を少なくした一一結果は本研究の結果と一致する。以 上から，対面してゲームをすることは最低得点の保証さ れていない0やマイナス得点を含むゲームでは競争選択 を抑制し，最低得点の保証されているプラス得点のみの ゲームでは競争選択を促進する効果をもたらすと考兄ら れる。

しかし，この対面の効果がゲーム行動として表われる 早さは（十・一）ゲームと（十）ゲームとでは異なって いた。つまり（十・文)ゲームの対面群のプレイヤーは ゲームの進行に伴いペアの両者が共栄セルを志向し次第 に競争選択を少なくしたが，(十)ダームの対面群のプレ イヤーはゲームの初期から共貧セルに閉じ达められ競争 選択を多くとった。吉田 (1978)，山内・狩野 (1980) は，一方のプレイヤーが協同選択あるいは競争選択を多 くするとき相手プレイヤーがそれに伴って同じ選択を多 くする傾向は，協同選択よりも競争選択の場合の方が強 いといら結果を報告している。よって PD ゲームでは $\left(\mathrm{X}_{1}, \mathrm{X}_{1}\right)$ の共栄セルよりも $\left(\mathrm{X}_{4}, \mathrm{X}_{4}\right)$ の共貧セルの方 が早く出現しやすいと考觉られる。このために(十・一) ゲームでは対面したプレイヤーが志向した協同選択はゆ るやかに増加し（十）ゲームでは対面したプレイヤーが 志向した競争選択はゲーム開始直後から多かったのであ ろらと考えられる。

それでは，対面の效果がなぜゲーム構造の違いによっ て競争選択を抑制したり促進したりするのであろらか。 本研究の (十・一) ゲームでは，自己の得点を相手より 多くしょうとして競争選択をとれば，格差セルや共貧セ ルが実現してマイナス得点が避けられないので，自他の 一定の絶対得点が確保できない。よって，(十・ー）ゲー ムでの競争選択ほプレイヤーに相手プレイヤーとの心理 的緊張をもたらすと考えられる。そして，対面するプレ イヤーはしないプレイヤーよりこの心理的緊張を強く認 知するであろう．そのため，対面するプレイヤーの競争 選択は対面しないプレイヤーのそ机よりも少なかったの
であろう、これに対し（十）ゲームでは両プレイヤーが いかなる選択の組み合わ㞾を取っても 2 人ともにある程 度の得点が期待される.よって, (十) ゲームのプレイヤ 一は心理的緊張をもたらされずに競争選択をとることが でさるだろう。皇して，対面するプレイヤーはそらでな いプレイヤーよりも相手に対する関心が高まるために， 自他の最低得点を保証しょうとする動機だけでなく相手 より自己の得点を高くしたいといら動機をも強く喚起さ れると考光られる。対面するプレイヤーは相手より自己 の得点を高くしようとして競争選択を対面しないプレイ ヤーよりも多くしたのであろら。つまり，対面すること による相手プレイヤーへの関心の高まりは（十・ー） ゲームでは互恵への志向による競争選択抑制の機能を, (十)ゲームでは相対的優位への志向による競争選択促進 の機能を持つと考えられる. そして，これらの結果は， 他者との共行動は可能な全ての行動ではなく課題に適合 すると認知される行動を促進させるといら Zajonc \& Sales (1966) の結果とも一致すると考兄れる.

そこで, 梅岡・篠塚 (1966), 斉藤・紧玉・潮田 (1971) の研究抢よび本研究の結果から次のように考兄れる. 2 人 (Dyad) 協同・競争過程には相手と均等な関係を保 とうとする行動と相手より優位に立とうとする行動とが あり，当事者がいずれの行動を多く生起させるかは課題 特性, 対面の有無, 第 3 者の介在等の要因に規定される であうう．Deutsch (1978）は報酬分配の仮説として, “対面する関係が継続すればする汪ど親近感が増し，そ の関係から生まれるものを均等に分配しょうとするであ ろら。”と述べている. しかし，この仮説についても， 対面する 2 者が当面している課題の特性を考慮して吟味 する必要があると考えられる。

以上，対面はプレイヤーに対して課題適合性の高い行 動を促進させる效果を持つことが分かったが，対面がプ レイヤーにとってどのような情報的価值を持つかという 点は十分明らかにされなかった. Wichman (1970) は対 面の效果はゲーム進行中に常に相手を相互に視覚的に認 知劣るためにもたらされると考えている。乙かし，本研 究では，対面は (十・一) ゲームでは協同選択の促進, (十）ゲームでは競争選択の促進といらかたちをとった のでゲーム行動として表われる早さが異なったが，いず れのゲームに和いてもゲーム開始直後から協同選択傾向 㐫るいは競争選択傾向といらプレイヤーの選択傾向に影 響を和よぼしたと考えられた。そらすると，対面の効果 はプレイヤーがゲーム開始時に対面し相互に見知ったこ とによってもたらされたとも考光られる。すなおち，対 面の效果は，椙互に匿名性が失われたことによって相手 の存在がより強く意識されるためにもたらされるのでは ないかとも考えられる．この点の具体的解明には，今後 の研究に执いてプレイヤーが刘面する時期，ゲーム以前 
のブレイヤー間の関係等に検討を加える必要があろう。

また，対面の効果がゲーム構造によって異なることを 示すために, 本研究ではマイナス得点を含むゲームとプ ラス得点のみのゲームに和けるゲーム行動を検討しよう と, IC の等しい (十・ー) ゲームと（十）ゲームを 1 種 類ずつ作成して実験を行なった。乙かし，本実験の結果 をさらに明膫にするためには，(十・一）型のゲームと (十）型のゲームをそれぞれ多数個用意してそれらに和 沙る対面の効果を検討するといらアプローチを必要と思 われる。

\section{要約}

本研究は囚人のディレンマゲームに拈けるゲーム行動 に持よぼす詨面の効果を分析するために計画された。

実験Iでは，ゲームマトリックスはプラス得点とマイ ナス得点の両方を含むものであり，このゲームは（十・ 一)ゲームと呼ばれた．被験者は 24 名（12ペア）の大 学生女子であった。彼らは対面条件之非対面条件に同数 ずつランダムに分けられた。ダームは 20 試行であった。 選択反応の結果から，対面条件下の被験者は非詨面条件 下の被験者よりも競争的でない行動をしていることが分 かった。

実験扛では，ゲームマトリックスはプラス得点のみで 作られて和り，このゲームは（十）ゲームと呼ばれた。 被験者は 24 名（12 ペア）の大学生女子であった。彼ら は対面条件と非対面条件に同数ずつランダムに分けられ た.ゲームは 20 試行であった. 選択反応の結果から, 対面条件下の被験者は非対面条件下の被験者よりも競争 的に行動していることが分かった.

これらの知見から次のよらな考察が行なわれた。（十・ 一) ゲームは被験者に競争選択よりも協同選択を優勢に (dominantly) 動機づけるゲームと考觉られる。なぜな らば，被験者は自分がマイナス得点を取ったり相手プレ イヤーにマイナス得点を取らせることを避けるためには 協同選択をしなければならないからである。しかし， （十）ゲーム以被験者に協同選択よりも競争選択を優勢 に動機づけるダームと考えられる。(十)ゲームではいか なる選択をとっても対の被験者は共にプラスの得点が与 えられる。よって被験者はそれぞれ相手より高い得点を 得るよう競争選択を動機づけられるからである，2つの 型のゲームに扝ける対面の效果はこのような優勢な選択 行動の促進と考えられた。

\section{引用文 献}

Deutsch, M. 1978 The social psychology of justice. 国際社会心理学シンポジウム (京都) 発表論文集, 2346.
E11s, J. G., \& Sermat, V. 1968 Motivational determinant of choice in Chiken and Prisoner's dilemma. Journal of Conflict Resolution, 12, 374-380.

Minas, J.S., Scode1, A., Marlowe, D., \& Rawson, H. 1960 Some descriptive aspects of two-person non-zero-sum games. II. Journal of Conflict Resolution, 4, 193-197.

Nemeth, C. 1972 A critical analysis of research utilizing the prisoner's dilemma paradigm for the study of bargaining. In L. Berkowitz (Ed.), Advances in experimental social psychology. Vol. 6. New York : Academic Press. Pp. 203-234.

Rapoport, A. 1967 A note on the index of cooperation for Prisoner's Dilemma. Journal of Confict Resolution, 11, 100-103.

Rapoport, A., \& Orwant, C. 1962 Experimental games: A review. Behavioral Science, 7, 1-37.

斎藤 勇 1975 逐次選択方式によるプリゾナーズ・デ ィレンマゲームに和ける対人行動と選択動機の分析 実験社会心理学研究，15, 129-141.

斎藤 勇 - 児玉昌久 ・潮田武彦 1971 内集団関係 - 外 集団関係に括ける個人間の協同・競争 心理学研究, 42, 310-314.

Terhune, K.W. 1968 Motives, situation and interpersonal conflict within prisoner's dilemma. Journal of Personality and Social Psychology, 8, (Monograph), 1-24.

梅岡義貴・篠塚寛美 19662 人非零和ゲームの実験的 考察（2），（3）日本心理学会第 30 回大会発表論文 集, 338-339.

Wichman, H. 1970 Effect of isolation and communication on cooperation in a two-person game. Journal of Personality and Social Psychology, 16, 114-120.

山内隆久・狩野素朗 1979 ゲーム事態に括ける対人相 互作用に和上活与先行共有経験の效果 九州大学教育 学部紀要, 24, 69-79.

山内隆久・狩野素朗 1980 ゲーム行動に和よぼすパー トナーの協同選択率の变化の效果 九州大学教育学部 紀要, 25, 89-95.

吉田富二雄 1978 社会的相互作用場面に括ける対人認 知の研究 (1)—ー゙ーム行動の分析を通して——実 験社会心理学研究, 18, 11-20.

Zajonc, R. B. 1965 Social facilitation. Science, 149, 269-274.

Zajonc, R. B., \& Sales, S. M. 1966 Social facilitation of dominant and subordinate responses. Journal of Experimental Social Psychology, 2, 160-168.

—1980.10.19. 受稿, 1981.11.4. 受理— 